FRANZISKA E. SHLOSSER / MONTREAL

\title{
THE EXARCHATES OF AFRICA AND ITALY
}

\section{Justinian's Arrangements for Africa after the Reconquest}

In order to arrive at some understanding of early Byzantine government in the days of the Emperor Maurice, we ought to consider first the one distinctive administrative change that seems to have occurred during the reign of this emperor: the establishment of the Exarchates of Ravenna and Carthage. Yet the beginning of so important an institution as this, is nowhere testified in our sources. The first mention of an exarch in Italy is to be found in a letter of Pope Pelagius II, in 584. ${ }^{1}$ Therefore, we must go back to what happened earlier in Africa and Italy after Justinian's reconquista in the West in order to be able to grasp the changes that had taken place and evaluate their significance.

At the time that Belisarius restored Africa to the Empire, Justinian issued guide lines for the reconstitution of Roman rule over the territory of the conquered Vandals. One part of this document is addressed to the newly created Praetorian Prefect of Africa, Archelaus, ${ }^{2}$ the other part to Belisarius, Magister Militum per Orientem ${ }^{3}$. The former establishes the extent and limit of the new prefect's power, whereas the latter is an order to Belisarius to take measures for the safety of Africa.

The praefectus praetorio Africae is to enjoy the same dignity as his colleagues of the Orient and Illyria, and he is to reside in Carthage. The

${ }^{1}$ Greg. Register 1/2, Appendix II: ... quia maxime partes Romanae omni praesidio vacuatae videntur et exarchus scribit nullum nobis posse remedium facere, ... . P. GOUBERT, Byzance avant l'Islam, II/2: Byzance et Carthage. Paris 1956/1965, 79; Ch. Dient, Études sur l'administration byzantine dans l'Exarchat de Ravenne (568-751). Paris 1888, 173; L. M. HaRtmann, Untersuchungen zur Geschichte der byzantinischen Verwaltung in Italien (540-750). Leipzig 1889 (Repr. New York n.d.), 2; M. Vallejo GiRvés, Byzantine Spain and the African Exarchate: an Administrative Perspective. JÖB 49 (1999) 13-23. For an earlier detailed account of sources pertaining to the Exarchates see: Dient, Exarchat, and idem: L'Afrique byzantine: histoire de la domination byzantine en Afrique (533-750). Paris 1896.

${ }^{2}$ CI 1.27.1; see also PLRE III, Archelaus.

${ }^{3}$ CI 1.27.2; see also PLRE III, Belisarius 1. 
Emperor salutes his new official as tua excellentia ${ }^{4}$ under whose jurisdiction he places seven provinces, four of which Tingitania, Carthage, Byzacena and Tripoli, are assigned to the care of governors (consulares $)^{5}$ while three others, that is, Numidia, Mauritania and Sardinia, are to be controlled by praesides. ${ }^{6}$

The prefect is given a staff of three-hundred and ninety-six people who are distributed among the civilian and military departments. ${ }^{7}$ There is an additional staff of fifty attached to the offices of the provincial governors, whether they are consulares or praesides. ${ }^{8}$ These large numbers of officials are entitled to emoluments ex officio eorum de publico. ${ }^{9}$

Justinian does not miss the opportunity to give stern warning to his representative, the praetorian prefect, that omnes iudices nostri must discharge their duties honestly and free of cupidity and avarice. ${ }^{10}$ If justice is being upheld in Roman government, says the Imperial legislator, God will be pleased and Roman subjects will enjoy freedom after their long captivity under the barbarian yoke.

There are also regulations as to how much the judges of Africa will have to pay for their initial commission and in the event of further promotion. ${ }^{11}$ The document finishes with a list of all the salaries for the various officials in the administration of Africa. ${ }^{12}$

Corresponding to the civil arrangements, Justinian issues orders to Belisarius as military leader of the African expedition, saying that after

${ }^{4}$ CI 1.27.1, 11: Cuius sedem iubemus esse Carthaginem et in praefatione publicarum chartarum praefecturis aliis eius nomen adiungi, quam nunc tuam excellentiam gubernare decernimus.

${ }^{5}$ CI 1.27.1, 12. ... Carthago et Byzacium ac Tripolis rectores habeant consulares:...

${ }^{6}$ CI 1.27.1, 12: ... Numidia et Mauretaniae et Sardinia, a praesidibus cum dei auxilio gubernentur.

${ }^{7}$ CI 1.27.1, 13: Et in officio quidem tuae magnitudinis nec non pro tempore viri magnifici praefecti Africae trecentos nonaginta sex viros per diversa scrinia et officia militare decernimus.

${ }^{8}$ CI 1.27.1, 13 .

${ }^{9} C I 1.27 .1,14$.

${ }^{10}$ CI 1.27.1, 15: Optamus ergo, ut omnes iudices nostri secundum voluntatem et timorem dei et nostram electionem atque ordinationem sic suas administrationes gubernare studeant, ut nullus eorum aut cupiditati sit deditus aut violentias aliquas vel ipse inferat vel iudicibus aut officiis eorum aut quibuscumque aliis collatoribus inferre permittat.

${ }^{11}$ CI 1.27.1, 19: Iubemus ergo, ut iudices dioeceseos Africanae tam civiles quam miltares in nostro laterculo pro codicillorum atque chartularum promotionis suae consuetudinibus nihil ultra quam sex solidos praebeant, at vero in scrinio praefectorum non ultra duodecim solidos cogantur inferre.

${ }^{12}$ CI 1.27.1, 21-24. 
the administration of Africa has been re-established, the armies and their leaders must then be distributed in accordance with Imperial wishes. ${ }^{13}$

Justinian delineates the centres of military organization in Africa, and he details the capitals in which each $d u x$ is to reside. ${ }^{14}$ Furthermore, Belisarius is ordered to station a tribune opposite Septa to watch all movements in Visigothic Spain, Gaul and the country of the Franks. In case of trouble, the line of communications is clearly indicated: the tribune must report immediately to his superior, the $d u x$, and he, in turn, will send the information to the praetorian prefect. In addition, a number of ships are to be stationed in the straits for service when needed. ${ }^{15}$

The general tenor of Justinian's instructions is one of urgency and of anxiety not to lose again what has been won almost miraculously. The Emperor issues orders for fortifying the borders of the reconquered territory, and with a sigh he asks how many soldiers Belisarius will need to achieve all of this. ${ }^{16}$

To maintain secure borders, Justinian endeavours to establish a frontier line: a fortified limes with soldiers who could defend as well as cultivate the area and who would aid the comitatenses milites per castra when the need arose. ${ }^{17}$ Conversely, these border troops must be able to fend for themselves without the help of other armies. There follows a strict warning that soldiers and officers of the frontier troops must not attempt to extend the boundaries of their respective territories. ${ }^{18}$

The rest of Justinian's instructions concern themselves mainly with army discipline of all the troops, whether they be field armies or border guards. The officers ought to keep their men employed and under constant military exercise. Excessive leave of absence is not to be given to soldiers since they may attempt to earn money for themselves and leave the provinces unguarded. ${ }^{19}$ So much for the discipline of Justinian's army.

\footnotetext{
13 CI 1.27.2.

$14 C I 1.27 .2,1 \mathrm{a}$.

15 CI 1.27.2, 2 .

16 CI 1.27.2, 5 .

17 CI 1.27.2, 8.
}

${ }^{18}$ CI 1.27.2, 8:... non longe limitem exeuntes nec ipsi limitanei nec duces eorum ... . J.B. Bury, A History of the Later Roman Empire II. New ed. (A.D. 395-565). London 1923 (Repr. 1958), 142. For a comprehensive study of the Roman defence system in Africa see Dient, L'Afrique, passim; H. v. Petricovits, Die Eroberung und Sicherung des nordafrikanischen Vandalengebiets durch Ostrom. Jahrbuch Akad. Wiss. Göttingen 1976 , 53-77; R. Rebuffat, Une zone militaire et sa vie économique. Le limes Tripolitaine, in: Armées et fiscalité dans le monde antique (Coll. nat. CNRS 936). Paris 1977, 395-419.

${ }_{19}$ CI 1.27.2, 9. Et unumquemque ducem et tribunos eorundum militum iubemus, ut semper milites ad exercitationem armorum teneant et non concedant eos divagari, ut, si quando 
When Belisarius has carried out these Imperial dicta, he must then return to Constantinople. After his departure, the commanders of the various armies are to turn to the praetorian prefect for any new arrangement they might wish to make; for the money to pay their troops and for provisions. This part, too, ends with a list of all the salaries for the military who, generally speaking, seem to be better paid than their civilian counterparts. ${ }^{20}$

In this document we have the outline of how Justinian envisioned the governing of Byzantine Africa. There is certainly no indication that the Emperor intended to depart from forms of administration which had existed in Africa before the Vandal conquest. On the contrary, here as elsewhere, Justinian wanted to show his subjects how blessed those people were who lived under Roman rule, and for that reason he would restore the old way of life. As so often, however, at this late period in Roman history, the ruling power had to adjust to the realities and necessities of life. The most striking reality in this case, and one which did not allow Justinian simply to return to the status quo ante, was the fact that Italy, to whose sphere of influence Africa had previously belonged, was still under Gothic rule. On account of this, the Emperor had to add a third high-powered official to his administration and thereby created a praefectus praetorio Africae. ${ }^{21}$

All did not work according to the plans conceived in the Imperial mind, and after Belisarius had departed from Africa the Moors rose in rebellion. Justinian sent one of Belisarius' commanders, Solomon, to remain in Africa as the first magister militum per Africam..$^{22}$ This officer was soon to hold the post of praetorian prefect in addition to his military command, and the Novels of Justinian, which were issued in 535 to regulate the difficult question of land ownership in the conquered territory and to re-establish the Church of Africa, were addressed to Solomon, praetorian prefect of Africa. ${ }^{23} \mathrm{It}$ is in his person that we see the two high offices combined for the first time in Byzantine Africa.

necessitas contigerit, possint inimicis resistere: et nullum audeant duces aut tribuni commeatalem de ipsis dimittere, ne, dum sibi lucrum studeant conficere, incustoditas nostras relinquant provincias. See also Mauricii Strategicon, ed. G.T. Dennis, German translation by E. Gamillscheg (CFHB XVII). Vienna 1981, I.7.14; Maurice's Strategicon, trans. G. T. Dennis, Philadelphia 1984, 19.

${ }^{20}$ CI $1.27 .2,20-35$.

${ }^{21}$ The other Praetorian Prefectures at this time were: Illyricum and the East.

${ }^{22}$ Proc., $B V$, IV.x.1.

${ }^{23}$ CIC III, Nov. 36, 37; see also PLRE III, Solomon 1. 
ITALy AFTER THE RECONQUEST

In the meantime, developments had taken place that permitted Justinian to advance his most cherished plan, the reconquest of Italy. No sooner had Africa been temporarily pacified than the Emperor embarked on the long wars that led to the overthrow of Gothic rule in Italy. The conqueror of the Vandals, Belisarius, was sent west once more to start on a campaign in which he was to be largely successful, but the fruit of which was to fall to an other man.

Narses, the general who defeated the Goths decisively in 552, remained in Italy to reconstitute Imperial rule in the peninsula. It must be understood that it is only in this sense that Byzantine historians and chroniclers were to call Narses the "Exarch". ${ }^{24}$

Justinian issued a Constitutio pragmatica to order the affairs of reconquered Italy. ${ }^{25}$ The document has come down to us in twenty-seven points, one part of which is De suffragio collatorum, the mode of appointing civil governors in Italy. ${ }^{26}$ The Emperor does not intend to appoint such governors himself, nor would he have them appointed by any other person in his administration; they are to be elected by the bishops and the chief persons of each province and the judices are to be chosen from among the residents of the respective areas. There is to be no payment for votes: sine suffragio. ${ }^{27}$

Did Justinian wish to achieve honest local government? This is not an isolated attempt on the part of the Emperor to return to more self-sufficient smaller administrative units. Throughout his legislation, Justinian rails at governors who neglect their duties and thus force people to come to the capital in order to obtain justice. He may have hoped that locallyelected men would be more dependable, and could more easily be held responsible by the central government for their actions. There are various Novels that give an indication of the Emperor's desire to curb corruption. His tone with respect to legislation concerning these matters is often one of downright exasperation.

In addition, there is a new attitude in the regulations designed for Italy. In trying to find upright and unselfish individuals to oversee some functions

${ }^{24}$ Agathias I 7.8, 8.1 12.4, 13.5, II 6.1; Malalas 486, 15; Theophanes 6044; see also PLRE III, Narses 1.

${ }^{25}$ CIC III, Appendix VII.

${ }^{26}$ CIC III, Appendix VII, 12.

${ }^{27}$ CIC III, Appendix VII.12, 45. For officialdom in Italy in general, see T.S. Brown, Gentlemen and Officers: Imperial Administration and Aristocratic Power in Byzantine Italy A.D. 554-800. British School at Rome 1984. 
of government far away from the court of Constantinople, Justinian turns to the Church in the hope that men of God will act fairly and disinterestedly. It was also with this in mind that he entrusted the official weights and measures to the Pope and Senate of Rome. ${ }^{28}$

This search for individuals devoted to the state is in keeping with what we can glean from other sources of the time as well as from Justinian's legislation. There is a brief but highly significant statement in the introduction to the Anonymous. It is a description of the characteristics and functions of the different sections of society. As this military handbook probably belongs to the second half of Justinian's reign, it gives us insights into sixth-century Byzantine social structure, at least as seen from the hub of Constantinople. Among all the other groups the author of the treatise describes, he considers the priesthood to be the most noble occupation. The clergy, he says, must put purity of spirit first, since their judge is the Lord Himself. ${ }^{29}$ Thus it seems that the Emperor, casting around for honest and devoted men, unwittingly widened the base of the secular functions of the Church. This need not surprise us, since the well-being of the orbis Romanus and that of the Christian Church were concomitant in contemporary thinking. 30

Here it may be of interest to note that, in the same vein as the Anonymous, Justinian felt the need to stress this quality of devotion to the state when he wrote to Belisarius about the tribune to be posted at Septa. Justinian urges that the man must be "tribuno... prudente devotionem servante rei publicae nostrae per omnia". ${ }^{31}$ If we keep in mind the notorious situation that existed with regard to soldiers' loyalty on account of late pay, the concern expressed here was not unfounded.

Looking at Italy again in the days of the Emperor Maurice, we may ask ourselves what has happened since the end of the Gothic Wars. From

${ }^{28}$ CIC III, Appendix VII.19: De mensuris et ponderibus.Ut autem nulla fraudis vel laesionis provinciarum nascatur occasio, iubemus in illis mensuris vel ponderibus species vel pecunias dari vel suscipi, quae beatissimo papae vel amplissimo senatui nostra pietas in praesenti contradidit.

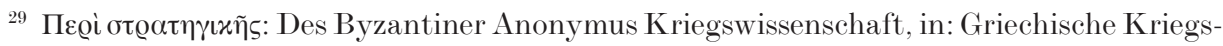
schriftsteller, edd. H. Köchly and W. Rüstow, Leipzig 1853-1855 (Repr. Osnabrück

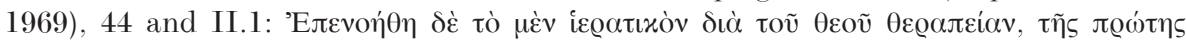
$\gamma \varepsilon v$

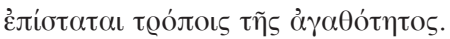

${ }^{30}$ O. Treitinger, Die oströmische Kaiser- und Reichsidee nach ihrer Gestaltung im höfischen Zeremoniell. Jena 1938 (Repr. Darmstadt 1956), passim; G. Ostrogonsky, A History of the Byzantine State, English tans. J.M. Hussey. Oxford 1968, 27.

${ }^{31}$ CI 1.27.2. 
about 584 onwards, we hear of an exarch in the peninsula, and there is no more talk of locally elected magistrates sine suffragio. The immediate successor to Justinian, Justin II, had tried to establish the elections of officials modelled on the Pragmatic Sanction of his predecessor; he seems to have failed, however, and the system of suffragium prevailed throughout the whole Roman world. ${ }^{32}$ But what had also happened since the passing of Gothic power was a new barbarian invasion of Italy with the coming of the Lombards.

Paul the Deacon relates the story of Narses who, when insulted by the Empress Sophia's sending him a golden distaff (meaning that the aged eunuch was fit to card wool in the women's quarters rather than to govern), is supposed to have vowed that he would indeed spin her a yarn and thus he called the Lombards into Italy. ${ }^{33}$

Whatever the truth of the story of Narses' disloyalty to the Empire may be, he was relieved of his post and, after retiring in 568 to Rome, he probably died there in 573 , having governed Italy for many years. ${ }^{34}$ Hence, the final development from the exceptional position that the eunuch had held for such a long time to the Exarchate falls into the time span from 568 to 584 , at which time the Exarch of Italy is first mentioned.

\section{The Exarchates}

Who the first exarch was, we may never know. The role that Narses played in Italy may have been that of exarch in all but name. But this conclusion remains one reached after the fact. As has been stated above, the first time we hear of an exarch in Ravenna is in 584 in a letter of Pope Pelagius II and the Exarch of Carthage is attested as late as 591.35

We may wonder not only how this title came into existence, but also what it meant to earlier generations, and what its evolution was.

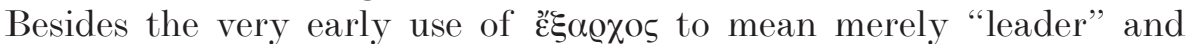
especially the leader of a chorus, we find the appellation used in Justinian's

${ }^{32}$ CIC III, Nov. 149 and 161; A. H. M. Jones, The Later Roman Empire, 284-602: A Social, Economic and Administrative Survey. Oxford 1964, I, 306.

${ }^{33}$ Paul. Diac. II.5; see also W. Goffart, The Narrators of Barbarian History (A.D. 550-800): Jordanes, Gregory of Tours, Bede and Paul the Deacon. Princeton 1988, 388-389, n. 184; T. Hodgkin, Italy and her Invaders. Oxford 1880-99 (Repr. New York 1967), V, 60-65.

${ }^{34}$ Paul. Diac.II.11.11. See also E. Stein, Studien zur Geschichte des byzantinischen Reiches, vornehmlich unter den Kaisern Justinus II und Tiberius Constantinus. Stuttgart 1919, 15-16 and 34, n. 17.

${ }^{35}$ Greg. Register I, 59; I, 27; I, 73. 
legislation simply to describe a military leader. It is thus not a title, but a descriptive term. That it was used in this sense in the Greek-speaking East at earlier times is furthermore attested by an inscription dating to the third century A.D., in which Odaenathus of Palmyra is referred to as है $\xi \alpha \varrho \chi o \varsigma$ $\Pi \alpha \lambda \mu v \varrho \eta v \tilde{\omega} v$. We know that Gallienus rewarded him with the title of $d u x$ for his services to the Empire in warding off the Persian danger. Thus the Greek approximation of $d u x$ is, in this case, ${ }^{\prime} \xi \alpha \varrho \chi 05$. We may muse about the possibility of the word having purposely been chosen for this Greek inscription because of its ambiguity, since we also know that Odaenathus had assumed the title of king in his own country and ruled there independently of Roman influence. Thus it seems possible that the referring to Odaenathus as exarch implies his sharing in the Emperor's powers by delegation. But the basic meaning is clear in any case - it describes leadership. ${ }^{36}$

Searching for some information on the Exarchate in the late sixth century, one would expect to find reference made to its establishment in Theophylact Simocatta. There is, however, no trace in the Histories of the title of exarch. That is, there is mention made of individuals whom we know to have been exarchs; yet, that appellation is not applied to them. Even Heraclius, the father of the Emperor of the same name, figures

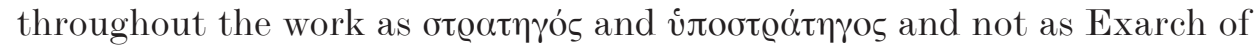
Carthage. ${ }^{37}$

There are possibly two reasons for this omission. First, if the Exarchates were not created by a great legislative act of the Emperor Maurice, it may not have made a sufficient impression on the minds of his contemporaries to be recorded. Secondly, at the time that Theophylact Simocatta wrote under Heraclius, western affairs no longer commanded a position of primary interest, since all the efforts of the Emperor were now concentrated against Persia. It is thus not surprising that contemporary testimony of the Exarchates comes from western sources; and it is natural that the epistles of Pope Gregory are the most important of these sources since he was closely involved in Italian affairs.

${ }^{36}$ Liddell and ScotT, An Intermediate Greek-English Lexicon. Oxford ${ }^{7} 1889$ (Repr. Oxford 1961), 271: “... the first in rank, chief, Lat. princeps...”; H. J. Mason, Greek Terms for Roman Institutions: A Lexicon and Analysis (American Studies in Papyrology 13). Toronto 1974, 43; L. M. Hartmann, Untersuchungen zur Geschichte der byzantinischen Verwaltung in Italien (540-750). Leipzig 1889 (Repr. New York, n.d.), 9.

${ }^{37}$ Theoph. Sim. II.3.2, II.5.10, II.6.4, II.7.11, II.9.17, II.10.1, II.18.1, II.26, III.1.1, III.6.2; see also M. Wнітву, The Emperor and His Historian: Theophylact Simocatta on Persian and Balkan Warfare. Oxford 1988, 46-79; see also PLRE III, Heraclius 3. 
The one virtue that this circumstance may have is that Gregory was not concerned enough with these letters to edit them for posterity and thus there is no "historical" view, such as Theophylact might have introduced had he cared to write about the Exarchates. On the contrary, we learn from the papal epistles about daily problems and issues that beset the relationship between Pope and Exarch.

To sum up, are we to think that Maurice had a grand vision or a reasoned policy of state, the result of which was the establishment of the two Exarchates? Or is their existence at the end of the sixth century rather the outcome of a long evolutionary process with its roots in earlier Roman traditions activated once more by the necessities of the day?

Let us consider for a moment the possibility that Maurice had tried to "establish" the exarchates and, if we allow ourselves to think of the matter in modern terminology, let us see what "model" would have recommended itself to the Emperor. The successors of Narses who were sent to Ravenna for the governing of Italy had as their main and primary concern the Lombard danger. Thus their role was not unlike that of the great military chiefs of barbarian origins who had been sent to Italy since the days of Honorius. The title of these earlier military leaders was normally magister militum and this was still the title of Theodoric, the Ostrogothic king, when he went west at the bidding of the Emperor Zeno. ${ }^{38}$

A new situation arose when Theodoric rid himself of Odovacer in a bid for supreme power in Italy. Anastasius, who had succeeded Zeno on the Byzantine throne, was at the time in no position either to recall or to destroy the Gothic host in the peninsula. Therefore, he did what had been done before in similar situations and acquiesced in the rule of Theodoric in Italy. Thus the Gothic king came to govern this western territory of the Empire as Odovacer had done before him. His officium was that of magister utriusque militiae, which in theory could be held by any other Gothic warrior, and he was further distinguished by having been consul and patricius, although the Byzantine emperors were soon to call him rex in their communications. ${ }^{39}$

${ }^{38}$ Bury, History, I, 422 and n.2.

${ }^{39}$ Cassiodorus VI.2; K. von Hegel, Geschichte der Städteverfassung von Italien, I. Leipzig 1847 (Repr. Aalen 1964), 99-109; Th. Mommsen, Ostgotische Studien, in: Gesammelte Schriften VI. Berlin/Zürich ${ }^{2} 1965$, 422-423; W. Exsslin, Aus Theoderichs Kanzlei. Würzburger Jahrbücher (1947) 75-86; W. G. Sinningen, Administrative Shifts of Competence under Theoderich. Traditio 21 (1965) 456-457. For a discussion of controversial interpretations and for detailed citations of sources see A. H. M. JonEs, The Constitutional Position of Odovacer and Theoderich. JRSt 52 (1965) 126-130. 
But it is precisely by the attribute of patricius that the Exarchs were to be distinguished. ${ }^{40}$

Thus it seems likely that the Byzantine officials who came to govern conquered Italy moved into the vacuum generated when there was no longer a Gothic king residing in Ravenna. The idea of an Imperial representative in the West still held a persuasive sway over people's minds. Yet it was a far cry from what Justinian had tried to establish. The exarchs were not elected, but appointed by the Emperor and, what was worse, they were not even of Italian stock. The sequel was to show that a Greek Imperial governor in Ravenna was not dearer to Roman hearts than a Gothic king had been.

That the Goths themselves tried to maintain their former relationship with Constantinople is clear from the negotiations of Totila, the Gothic king whose military successes allowed him to attempt to strike a bargain with the Emperor, in the hope of establishing a legally sanctioned presence of his people in Italy. ${ }^{41}$ He failed, and Justinian later on stipulated in his Pragmatic Sanction that after the reign of Theodahad the legislation enacted by his successors was to be invalid. In the Emperor's view, from Vitigis to Teias, the barbarian kings had been tyrants ruling illegitimately without a mandate. ${ }^{42}$

Notwithstanding the initial attempt of Justinian to give Italy a measure of self-government, matters seem to have developed differently from the very beginning. There was the long rule of Narses in the peninsula after his victory over the Goths and, after his retirement, we learn of the presence of a high official, the Exarch, with almost royal powers stepping into the place of the aged eunuch. This surely tells us something about the underlying forces that helped shape the administration of Italy at the end of the sixth century.

There was, and there would be for some time to come, a praetorian prefect in the peninsula. The administrative structure was largely main-

${ }^{40}$ Greg. Register I,32, I,59, I,72, I,73, VI,59, VII,2, VII,3, XIII,36. For a discussion of the literature on the Late Roman patriciate, see R. Mathiesen, Patricians as Diplomats in Late Antiquity. BZ 79 (1986) 35-49. Heraclius, the father of the Emperor of the same name, held the title of patricius as governor of Carthage, PLRE III, Heraclius 3. See also M. Valdejo Girvés, Byzantine Spain, 15, n. 12 and 13.

${ }^{41}$ Proc., BG VII.xxi, VIII.xxiv.4.

${ }^{42}$ CIC III, Appendix VII.1: Ut omnia firma sint, quae Amalasuinta vel Atalaricus vel Theodatus concesserunt... . Inprimis itaque iubemus, ut omnia quae Atalaricus vel Amalasuinta regia mater eius vel etiam Theodatus Romanis vel senatu poscente concesserunt, inviolabiliter conserventur. CIC III, Appendix VII.2: Ut per Totilanem factae donationes omnes irritae sint. 
tained as it had been before, but it was topped now by an official who would govern almost as independently as the Gothic king had done. In order to rule in this manner, the Exarch had to be also the commander-in-chief of the soldiers, which was and had been since the days of the Principate traditionally the real power base of anyone governing Italy.

Thus it is not surprising that Constantinople utilized an already existing machinery which, if only in the administrative sphere, had in the past remained Roman throughout and simply replaced the barbarian ruler with the Exarch. The bridge between the two was the retention of the title patricius for the latter, since the title magister militum had become so debased and had been granted indiscriminately to military leaders with a much less extensive mandate than that of the Exarch, who united the civil and military powers in his hands. ${ }^{43}$ There had been times during the wars with the Goths when conflicting opinions and outright jealousy between the commanders of Justinian's army seriously impaired the realization of strategic plans put forward by Belisarius whose authority had been limited by the Emperor. ${ }^{44}$ Therefore, the new appellation for the governor of Italy may have been no more than a practical solution applied to the problem of elevating one Imperial official sufficiently high as to rank above the officials dependent on his orders; and, at the same time, to fill the place in an administration which had grown accustomed to look towards a single individual who had been, at least to his own people, a rex..$^{45}$

That this hypothesis is not altogether unfounded may clearly be observed from the correspondence of Pope Gregory, who negotiated with the exarchs in no manner different from that of his predecessors with the barbarian rulers. ${ }^{46}$ Some actions of individual exarchs also indicate a measure of independent policy, as for instance in the case of Smaragdus when he arrested the church officials of Istria. Smaragdus' high-handed action happened to run counter to Imperial interests and he was recalled by the Emperor Maurice. It demonstrates, however, how dangerously powerful the

43 Th. Mommsen, Das römische Militärwesen seit Diocletian. Hermes 24 (1889) 260-268; A. Müller, Das Heer Justinians. Philologus 71 (1912) 105-107; R. Grosse, Römische Militärgeschichte von Gallienus bis zum Beginn der byzantinischen Themenverfassung. Berlin 1920, 180-190, 265, 297-299; JoNEs, LRE I, 341-344, 375-376, 380-381, II, 608-610; Hartmann, Untersuchungen, 9-33. For a different view see J. Durliat,

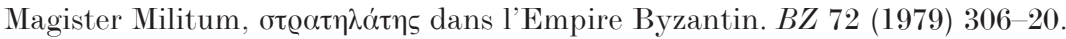

${ }^{44}$ Proc. BG VI.vii.25f., VI.x.1, VI.xiii.16, VI.xvi-xix.

45 G. Albert, Die Goten in Konstantinopel. Paderborn 1984.

${ }^{46}$ Greg. Register I, 32, I, 59, I, 72, I, 93, I, 238, III, 31, V, 19, VI, 59, VII, 3, VII, 42, IX, 9, IX, 44, IX, 141, IX, 154, XIII, 36. These letters bear testimony to the fact that the Pope kept his own responsales in Ravenna. 
exarch had become within his own sphere of influence. ${ }^{47}$ The other Exarchate, Carthage, had enjoyed on and off some measure of peace and prosperity. It had not been torn by as long a war as Italy, but it had been sporadically shaken by uprisings of the native tribes. Yet Africa was not immediately threatened as was the peninsula by the presence of the Lombards. It is true enough that Africa, too, was surrounded by hostile populations, but it was safer behind defensible borders than was Italy, where the enemy was literally within its boundaries creating barriers between the different administrative areas of the peninsula.

Regardless of similarities and dissimilarities, eventually we observe in Africa a system similar to the one in Italy and attested from 591 onwards. Historically speaking, there may have been several reasons for the parallel development in Africa and Italy.

At first, when Belisarius had won back Africa for the Empire, there had been frequent unrest among the Moors, who tried to grasp at the advantage of the hour and move into the place of the vanquished Vandals, just as Lombards and Franks were to attempt in Italy after the fall of the Goths. It may be remembered that this led to the uniting of civil and military responsibilities in the hands of Solomon. Another reason for the same type of administration that we finally find in Africa and Italy may simply be that both places were far removed from the areas of immediate Imperial concern, which, till 590, concentrated on Persia and afterwards on the Danube frontier. It was thus useful to place the western territories under high-ranking representatives of the Emperor for self-sufficiency, and to fill the gap that appeared after the fall of Vandal and Gothic rule.

There was little that the central government could spare for the protection of Africa and Italy. The best it was able to do, was to allow the exarchs as free a hand as possible and to keep a wary eye on their actions in order to replace them whenever they stepped too far out of line. Otherwise it would be difficult to understand why Maurice, who avoided sharing his power and who kept changing the commanders of his armies all too frequently, would acquiesce in, or even more surprisingly, create, so powerful a post as that of Exarch.

The reason that the development came first in Italy and, as far as our sources tell us, only later in Africa may be that the legal question that had to be considered after the reconquista in each territory was basically different.

Africa had been conquered by the Vandals as an enemy host with no pretence of a mandate given by Constantinople. Accordingly, the Vandals

${ }^{47}$ Goubert, Byzance, II/1, 88; see also PLRE III, Smaragdus 2. 
had taken the land and distributed it among themselves by the right of conquest. Therefore, the retaking of Africa was seen by Justinian simply as an act of repossession by the Romans, and the land was reclaimed as Justinian's legislation clearly shows. ${ }^{48}$

Not so in Italy. When Theodoric led his people into the peninsula, he did so, at least outwardly, with the sanction of the Emperor Zeno. Eventually the Gothic warriors received land, as had those of Odovacer before them, not as conquerors but, it is assumed, under legislation regulating the quartering of troops. Furthermore, Justinian started the Gothic wars ostensibly to set aright the injustices committed against the rightful heirs of Theodoric, and especially against his daughter, Amalasuntha. Although the Goths were chastised by the Emperor as a people who had failed to keep their side of an agreement, yet the reign of the house of Theodoric right down to that of his nephew, Theodahad, the murderer of Amalasuntha, was seen as legal and the legislation of the Amalian house remained binding. ${ }^{49}$

On account of Justinian's sanctioning the legislation of the Gothic kings of Theodoric's line, the affairs of Italy must be judged differently from those of Africa. It does not matter if we agree or disagree with those who argue that Theodoric was king only over his Goths, or over both the Roman and Gothic population, or if we concede that his authority had been granted by the Emperor or not. The acknowledgement of Gothic legislation goes far in giving a tint of legitimacy to Gothic rule in Italy.

Given those differences, there were some important features that the Exarchates of Carthage and Ravenna had in common since both were at the western extremities of the Empire. Both territories were far away from Constantinople and at times, especially during the winter season, communications were very slow and often disrupted. Furthermore, both Exarchates had come into existence in geographic areas once the very heartlands of Roman civilization, but recently ruled for a relatively long time as compact territorial units under the leadership of foreign rulers.

There is no knowing whether the Exarchates had been intended by Maurice as an interim measure only, a stop-gap as it were. The only hint that we have as to his real intention is in his testament. In this will, Tiberius, Maurice's second son, is one day to govern Rome, Italy and the islands of the Tyrrhenian Sea. ${ }^{50}$ We cannot discern from this arrangement

${ }^{48}$ CI 1.27.1, 1-9; especially 1.27.1,7: Nunc vero deus per suam misericordiam non solum Africam et omnes eius provinciales nobis tradidit, sed et ipsa imperialia ornamenta, quae capta Roma fuerant ablata, nobis restituit.

49 CIC III, VII.1.

50 Theoph. Sim. VIII.11.9; see also Whitby, The Emperor Maurice, 228. 
whether the Exarch of Ravenna would eventually have played the same role under Tiberius as the magister utriusque militae under Honorius. But given past experiences, such a solution could hardly have recommended itself to Maurice. Another curious fact is that Africa is not mentioned in the document at all. We may wonder if Maurice simply thought that it was to become a part of the Italian administration again, or if Theophylact Simocatta discreetly glossed over it since it was from there that Heraclius had come to free the Empire from the rule of Phocas.

It has been said, and not without justice, that all innovation in traditional societies takes the form of a restoration. Thus what is new must have the aura, at least in outward appearance, of some time-honoured institution. Maurice's testament seems to straddle both, the old and the new. In a way, it is a restoration of an earlier division of the Imperial power; in another way, with his younger sons to reign over the "rest" of the Imperial territories, it foreshadows new concepts of rule, such as the division of the Carolingian lands after the death of Louis the Pious, or later still, the apanage system of Kievan Russia.

Several modern scholars have also considered the Exarchates as indicative of the growing ascendancy of the military authority over the civil government, a development that reached its climax in the theme-organization of the eastern Empire. ${ }^{51}$ For a clearer comprehension of this, it must be regretted that we know very little about the social milieu from which, with a few possible exceptions, such as Heraclius, the father of the Emperor of the same name, the individual exarchs came. Yet we know generally that a number of fairly important military leaders, including Maurice himself, had been appointed to their military commands after an initial career in the civil administration. This means, in fact, that these men had a good literary education. Since we know from the Strategicon that literacy was not one of the virtues generally to be found in the army, this may indicate that selected men may have come to be preferred for higher military appointments and such posts as that of exarch because of better education and some experience in the administration. Thus there would have been an increasing infiltration of non-soldiers into the military establishment to the detriment of those officers who had formerly risen through the ranks. Here,

${ }^{51}$ Dienl, L'Exarchat, 31; Dient, L'Afrique, 472, 480, 502; Ostrogorsky, History, 68; Hartmann, Untersuchungen, 43, 51, 60-61, 69ff.; Th.I. Uspensky, Voennoe ustrojstvo vizantijskoj imperii. IPAIK 6 (1900) 154-207; trans. by J. Krenkov as "Military Organization of the Byzantine Empire." (This translation was made in 1945 and exists only in typescript at the Library of Congress, Washington, D.C.); H. Gelzer, Die Genesis der byzantinischen Themenverfassung. Leipzig 1899. 
too, we have exceptions on record, such as Heraclius, who is known in the

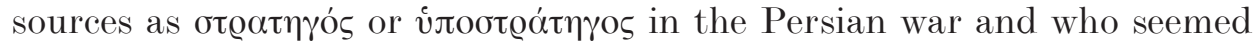
never to have held a civilian appointment. ${ }^{52}$ As, however, Maurice's reign was terminated by an army revolt carrying the unlettered Phocas to the throne of the Empire, it is not impossible that appointments of individuals to high military posts from the ranks of the bureaucracy or court circles led to the rise of a new officer corps, and, in time, to the estrangement of the rank and file. In this case, the rebellion of the army coming at a time when it had scored some success and felt its strength, may have partly been in response to the above policy.

Returning once more to the idea that Maurice had found and successfully applied an administrative "model" such as the Exarchates, we may rightly wonder why he did not establish this system in other regions also, especially in such endangered areas as the Danube frontier, or districts on the Persian border.

But if we were to look at the Balkan region, it seems doubtful that the same basis existed there for establishing an administrative unit like the Exarchate, and for the very reasons that the writer has cited in the previous discussion on Italy and Africa. The Balkans had never been central to Roman administration, but had always been a frontier region and, as such, the military leaders stationed there had in most cases reported directly to the emperor. Furthermore, as the defence of these areas was vital to the safety of Constantinople, it was usually supervised from the centre. ${ }^{53}$

The same is more or less true also of the Persian frontier. This was a very fluid border region with cities and populations changing masters constantly and it was virtually under martial law most of the time. Therefore, this area was often under military administration. ${ }^{54}$ Besides, the geographic regions of the Balkans and the Persian frontier had one feature in common, namely that they both lacked territorial compactness.

Justinian had tried to secure these areas by an elaborate system of fortifications and garrisons which, because of the shortage of funds and men, may have existed partly in design only ${ }^{55}$ These frontier regions had indeed very different traditions from those of the western lands of the Empire, which had enjoyed long periods of peace and prosperity before the

${ }^{52}$ See note 37 above.

53 CIC III, Nov. 26; Jones, LRE I, 280.

${ }^{54}$ CIC III, Nov. 30; Jones, LRE I, 280-283.

55 Procopii Caesariensis De Aedificiis Libri VI, in: Procopii Caesariensis Opera Omnia IV, ed. J. Haury. Leipzig 1913. Editio ster. corr. G. WirTh. Leipzig 1964, II.i-III.vii.25, IV.ix.18 fin. 
third century A.D. On account of their distinct needs, the eastern frontier as well as the Northern Balkan region had traditionally been placed under the command of duces and magistri. The office of dux had been throughout primarily a military post for strategic reasons, and most of the men who held such appointments had risen through the ranks. Thus the situation out of which the Exarchates developed in the West did not exist in the East.

Maurice, whose administrative tendencies were in general in favour of centralization where Justinian may have preferred creating self-sufficient and therefore more decentralized areas, would not have established such semi-independent units as the Exarchates in regions that were vital for the immediate safety of the capital. The Exarchates may therefore have been seen by Constantinople as a response to a need much more than an ideal general solution for the administration of the Empire.

From the foregoing, and considering once more the problem of growing military influence in the Empire, we may also surmise that there existed two sources producing the stream of candidates competing for the same high offices in the Empire: the bureaucracy and the army. It seems likely that by the time of the Emperor Maurice the conflict between these two interest-groups had become apparent once more. But the rising power of the military over the civil administration that was accelerated after the fall of Maurice may reach back much further to a time when the two rival groups within the administration of state started to vie for the same posts.

Concerning the economic life of the western territories, and especially the Exarchates, it is interesting to note that the mints were fully functioning in the times of Maurice and continued so, in fact, right into the time of Phocas. ${ }^{56}$ The western mints issued mostly gold and silver coins, the bulk

${ }^{56}$ DOC I-II, passim; W. Wroth ed., Western and Provincial Byzantine Coins of the Vandals, Ostrogoths, and Lombards and of the Empire of Thessalonica, Nicaea and Trebizond in the British Museum. London 1911 (Repr. 1966), 122; W.R.O. Haнn, Moneta Imperii Byzantini II: Von Justinus II bis Phocas (565-610). Vienna 1975, 5938; C. Morrisson, Catalogue des monnaies byzantines de la Bibliothèque Nationale I:

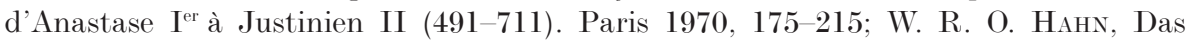
Römerreich der Byzantiner aus numismatischer Sicht. Numismatische Rundschau 65 (1986) 175-185, and especially 182-183. Hahn says, however, that: "Rom präsentiert sich also numismatisch gesehen im letzten Viertel des 6. Jahrhunderts als armselige 'Provinz' und ist weit entfernt von justinianischer Restaurationspolitik."; J. DURLiat, La valeur de l'or, de l'argent et du cuivre dans l'empire proto-byzantin ( $\mathrm{IV}^{\mathrm{e}}-\mathrm{VII}^{\mathrm{e}}$ siècle). Revue Numismatique 22/6 (1980) 138-154; C. Morrisson, Estimation du volume des émissions de solidi de Tibère et Maurice à Carthage (578-602). PACT 5 (1981) 267-283. As can be seen from the above there is disagreement concerning the extent of mint activity in Maurice's reign. 
of the copper coinage being produced in the East. Under Maurice, however, Ravenna, Carthage, Catania and Sicily did produce copper, which was an important factor in the collecting of taxes in the West. ${ }^{57}$ Thus smaller denominations returned as change to the hands of the population and must have circulated quite freely. This seems to indicate that the dark picture painted with regard to economic affairs in the late sixth century cannot be unqualifiedly true. With small denominations in circulation, the economy cannot have depended entirely on barter and, at least in monetary matters, there must have been a measure of stability in the reign of Maurice.

There is no denying, however, that for the people living in the Italian peninsula, it was a trying period. Again and again, Gregory the Great turned to the Imperial government for help, which was seldom forthcoming. Regardless of this, the Emperor would deal severely with the Pope whenever he tried, for the sake of Roman lives, to intercede in political affairs. ${ }^{58}$ Maurice who faced imminent danger in the East till 590, had to turn a deaf ear to the repeated sighs of the Bishop of Rome, who wrote that he lived constantly intra gladios Langobardorum. ${ }^{59}$

Not only had he to bear the inroads of the barbarians, but Gregory also had to intercede often on behalf of frightened Italian officials and clergy who feared the anger of Maurice or of his exarch whenever their actions incurred disfavour. ${ }^{60}$ It is this general situation that combined with the argument over the Constantinopolitan patriarch's use of the appellation of "oecumenical" patriarch, and the affairs of the Istrian Church, ${ }^{61}$ must account for the break in the relationship between Pope and Emperor.

${ }^{57}$ DOC I, 301-336, 338-352, 356-361, 362-365, 370-375; W. Wroth ed., Catalogue of the Imperial Byzantine Coins in the British Museum. London 1908, I, 130-154, 156-159; J. Sabatier, Description générale des monnaies byzantines, I, 240-250; Hahn, Moneta Imperii, 71-74; Morrisson, Monnaies byzantines, 178-179. Morrisson states, however, that the pentanoummia were struck at Constantinople, Nicomedia and Antioch only and are extremely rare for the latter two. M. F. Hendy, On the Administrative Basis of Byzantine Coinage c.400-900 and the Reforms of Heraclius. Historical Journal of the University of Birmingham 12/2 (1970) 129-154.

58 Greg. Register V, 36: Et quidem si terrae meae captivitas per cotidiana momenta non excresceret, de descriptione mea atque inrisione laetus tacerem. Sed hoc me vehementer affligit, quia unde ego crimen falsitatis tolero inde Italia cotidie ducitur sub Langobardorum iugo captiva dumque meis suggestionibus in nullo creditur, vires hostium immaniter excrescunt.

${ }^{59}$ Ibid.: Ego enim si fatus non fuissem, ad ista toleranda, quaeque inter Langobardorum gladios hoc in loco patior, minime venissem. Ibid. V.39: Viginti autem iam et septem annos ducimus, quod in hac urbe inter Langobardorum gladios vivimus.

${ }^{60}$ Ibid. I.32, X.12, XI.4; Hodgkin, Italy, V, 400.

${ }^{61}$ Greg. Register, V.37, V.39, V.41, V.44, V.45, IX.156; these letters are concerning the controversy over the use of the title "oecumenical bishop". Ibid. IX.153, IX.154, IX.155, IX.160; these letters are concerning the matter of the "Istrian schism". 
Italy had long been under its own administration. In fact it had been centralized locally since the days of Honorius. In Maurice's time we note a growing tension in the peninsula, since there were then two centres of political influence, namely Rome and Ravenna.

Honorius had moved his capital, and therewith the focal point of government, behind the protective walls of Ravenna during the height of the barbarian invasions. But now, with a strong Pope in Rome and only an Imperial representative in Ravenna, the Eternal City was on the ascendancy again rising toward the position she was to command in the Middle Ages. ${ }^{62}$

Autocrat as he was, Maurice may have wished to see his will enforced by the exarch in Italy till perhaps one day he would have his hands free again and could set things right once more in the West. But when the Empire was finally freed of the Persian danger, Maurice had to turn his efforts first to the troubled Danube frontier, which he might have succeeded in stabilizing had it not been for the untimely army revolt. There is no telling what his plans might have been for the reshaping of Byzantine rule in the West had his government survived this last insurrection.

The Emperor was fortunate in his choice of an exarch in Africa. With Heraclius the Elder in Carthage, government seems to have been smooth and well conducted since there was no other centre of gravity to introduce elements of disunity such as we surmise to have existed in Italy.

Generally speaking, feelings in the peninsula must have been very bitter indeed, as we can learn from Pope Gregory's epistles. When the quarrel between the Pope and John the Faster was at its height, Gregory wrote to his responsalis, Sabianus: "[You have not considered,] I can see, how craftily this [the imperial disfavour of Gregory] was managed by our aforesaid brother John [the Patriarch]. Evidently he did it in order to put me in this dilemma. Either I must listen to our Lord the Emperor, and so confirm the Patriarch in his vanity, or not listen, and so rouse the Imperial mind against me". ${ }^{63}$ No doubt, for Gregory, the representative of this "Imperial mind" was the Exarch of Ravenna. And a little further on in the same letter,

${ }^{62}$ Hegel, Geschichte der Städteverfassung von Italien, I, 163-165, 199: „Der römische Bischof betheiligte sich mit eigenen Kräften an dem Kampfe gegen die Barbaren und erhob sich zugleich als selbstständige vermittelnde Macht über den kriegführenden Völkern. Gregor der Grosse legte den Grundstein zu dem gewaltigen Aufbau des Papstthums."

${ }^{63}$ Greg. Register V, 45: Tamen qua callididate a praedicto fratre nostro Iohanne factum sit, suspicor, minime pensati. Idcirco enim hoc ille fecit, ut audiretur domnus imperator et ille in sua vanitate confirmatus esse videretur aut non a me audiretur et eius animus contra me irritaretur. Hodgkin, Italy , V, 395; the translation used above is Hodgkin's. 
Gregory's resentment of Byzantine rule in Italy finds full expression: "For after we have found that we could in no way be defended [by the Greeks] from the swords of our enemies, after we have lost for our devotion to the Republic, silver, gold, slaves, and raiment, it is too disgraceful that we should, through them, lose our faith also." ${ }_{64}$ But regardless of religious sentiment, what seems to have been the real issue behind the Pope's anger was that Gregory felt that only he represented the true interests of Italy as opposed to the pretensions of an Emperor who expected unquestioning submission to his orders without being able to give the necessary protection to his western subjects. This had to lead eventually to open conflict, since submission to any power will only be acceptable if the strong hand not only coerces, but also protects.

Thus it can finally be seen that the administrative concept of the Exarchate was not easily applicable to all areas alike, and Italy and Africa must be viewed as an exceptional solution initiated by the Byzantine government in outlying districts in the time of the Emperor Maurice.

If we can accept the above statements as correct, we may then regard the administrative changes in Maurice's reign in both the army and civilian sphere for what they seem to have been; that is, as attempts to solve the most pressing problems as they occurred. But they do not necessarily represent a grand scheme for reshaping the machinery of the Empire.

${ }^{64}$ Greg. Register V, 45: Postquam enim defendi ab inimicorum gladiis nullo modo possumus, postquam pro amore reipublicae argentum, aurum, mancipia, vestes perdidimus, nimis ignominiosum est, ut per eos etiam fidem perdamus. HodgKIn, Italy, V, 395; the translation above is Hodgkin's. 
